\title{
A review of the vector management methods to prevent and control outbreaks of West Nile virus infection and the challenge for Europe
}

\author{
Romeo Bellini ${ }^{*}$, Herve Zeller ${ }^{2}$ and Wim Van Bortel ${ }^{2}$
}

\begin{abstract}
West Nile virus infection is a growing concern in Europe. Vector management is often the primary option to prevent and control outbreaks of the disease. Its implementation is, however, complex and needs to be supported by integrated multidisciplinary surveillance systems and to be organized within the framework of predefined response plans. The impact of the vector control measures depends on multiple factors and the identification of the best combination of vector control methods is therefore not always straightforward. Therefore, this contribution aims at critically reviewing the existing vector control methods to prevent and control outbreaks of West Nile virus infection and to present the challenges for Europe.

Most West Nile virus vector control experiences have been recently developed in the US, where ecological conditions are different from the EU and vector control is organized under a different regulatory frame. The extrapolation of information produced in North America to Europe might be limited because of the seemingly different epidemiology in the European region. Therefore, there is an urgent need to analyse the European experiences of the prevention and control of outbreaks of West Nile virus infection and to perform robust cost-benefit analysis that can guide the implementation of the appropriate control measures. Furthermore, to be effective, vector control programs require a strong organisational backbone relying on a previously defined plan, skilled technicians and operators, appropriate equipment, and sufficient financial resources. A decision making guide scheme is proposed which may assist in the process of implementation of vector control measures tailored on specific areas and considering the available information and possible scenarios.
\end{abstract}

Keyword: West Nile virus, Vector-borne disease, Vector surveillance, Vector control, Europe

\section{Introduction}

West Nile virus (WNV) infection is a viral disease transmitted by mosquitoes and distributed worldwide. The virus is primarily maintained in an enzootic cycle involving a number of wild birds and ornithophilic mosquito species. When the climatic or environmental conditions become favourable the virus circulation may increase and transmission to other susceptible hosts such as humans and equids may occur. These are considered dead-end hosts because the viremia remains at a level not suitable for mosquito infection [1,2]. The vast majority of human cases remain asymptomatic and severe

\footnotetext{
* Correspondence: rbellini@caa.it

'Centro Agricoltura Ambiente "G.Nicoli", Via Argini Nord 3351, Crevalcore 40014, Italy

Full list of author information is available at the end of the article
}

neuroinvasive illness is reported in less than $1 \%$ of infected people $[3,4]$. The high number of non-symptomatic cases may increase the risk of WNV transmission through blood donation or organ transplants. WNV can be transported over long distances in migratory birds. While resting in wetland areas they might come in contact with the local mosquito species, and possibly initiate a local amplification cycle. In temperate regions the virus may overwinter in female mosquitoes as well as in birds, so there is no need for continuous re-introductions [5-10].

WNV infection is a growing concern in Europe. The infection has been documented since the early 1950s in several countries of the European Union (EU) [11]. In 1996, Romania reported the largest outbreak of WNV infection in humans to date inside the EU, with over 390 
confirmed cases [12]. From 2000, human cases and outbreaks in the EU and Balkan countries have been reported in Albania, Austria, Bosnia and Herzegovina, Bulgaria, Croatia, Czech Republic, The Former Yugoslav Republic of Macedonia, France, Greece, Hungary, Italy, Kosovo, Montenegro, Portugal, Romania, Serbia, and Spain [13-27]. In Europe WNV has been found in several field collected mosquito species, such as Culex pipiens s.l., Culex modestus, Culex univittatus, Coquillettidia richiardii, Aedes cantans, Aedes caspius, Aedes excrucians, Aedes vexans, Anopheles maculipennis s.s. and Anopheles atroparvus [11,28-32], but based on the current evidence the major vector role in outbreaks of WNV infection in Europe seems to be covered by $C x$. pipiens s.l. [12,31,33] with $C x$. modestus playing a role in specific regions [34].

The prevention and control of outbreaks of WNV infection are complex and need integrated multidisciplinary surveillance systems and response plans [35]. The integrated vector management (IVM) is the primary option to prevent and control outbreaks. The WHO defines IVM as "a rational decision-making process for the optimal use of resources for vector control" [36]. IVM is intended to utilize the best cost-benefit combination of all available control methods in a sustainable way respecting the environment in order to reduce the vector density and/or the vector-human contacts to levels not posing a public health concern. Yet, the implementation of IVM is hampered by the complexity of the WNV transmission cycle, the difficulties in estimating the size of the forthcoming outbreak in a timely matter and the related risk assessment. Moreover, the information necessary to make a robust cost-benefit analysis that guides the implementation of the appropriate measures is largely missing, as well as the species-specific WNV vector density thresholds, and the fact that mosquito control programs mostly rely on empirical data and past experience. The identification of the best vector control methods is therefore not always straightforward. Hence, this contribution aims at reviewing the existing vector control methods to prevent and control outbreaks of WNV infection and to present the challenges in a European context.

\section{Review}

The data bases PubMed and Promed were searched using the key words: West Nile, West Nile control, West Nile prevention, West Nile and cost benefit, Culex pipiens, Culex and overwintering, Culex pipiens and resistance, adulticide, aerial spray, larval control, larval management, mass trap, overwintering, ULV. The most important relevant accessible reports and unpublished documents were consulted and expert colleagues were contacted to provide additional information.

In the context of the EU WNV and blood safety preparedness plan an affected area is defined as an area with at least one case of WNV infection in humans according to the EU case definition [37]. Assigning an area as an affected area triggers the implementation of control measures. Hence this trigger, one case of WNV infection according to the EU case definition, was used as a definition of an outbreak in this paper. Prevention of WNV infection is intended before the occurrence of equine or human cases, while control of WNV infection is considered following the occurrence of at least one case of WNV infection.

\section{Control measures targeting the mosquito larvae}

In the context of outbreak prevention of WNV infection the objective of larval control is to contain immature stages in order to keep adult mosquito populations at density levels below which they pose a public health risk. Unfortunately, insufficient information exists to establish a larval density threshold that can be used to guide control operations [38-40]. The role of larval control to contain outbreaks of WNV infection should be considered as part of an IVM program (see Vector control decision making process section). Hence a larval control program must be in place in the areas known as susceptible to outbreaks of WNV infection (see Vector control decision making process section, Table 1).

\section{Environmental management and source reduction}

These activities have the important advantage over direct vector control operations to be long lasting or even permanent in their effects, thus allowing a positive cost-benefit balance. To appropriately adopt environmental management practices field investigations should be performed in advance to characterize and geo-reference breeding sites. Skilled technicians should conduct field inspections to cover at least one whole favourable season, mapping the potential and active breeding sites, defining their dimensions, accessibility, mosquito productivity by species, environmental value taking into account biodiversity issues especially when dealing with natural protected areas, seasonal dynamic, and indicating possible management actions. Source reduction can include simple activities such as the proper disposal of containers in backyards and the cleaning of rain gutters by property owners, to agronomic practices aimed at the reduction of standing waters, to extensive regional water management projects on public land. All these activities eliminate or substantially reduce mosquito breeding habitats and diminish the need for repeated application of insecticides [41-52].

\section{Biological larval control}

Direct biological larval control includes methods to enhance the activity of natural antagonists by introducing 
Table 1 Overview of the vector control methods currently used for the prevention and control of outbreaks of WNV infection

\begin{tabular}{|c|c|c|c|c|}
\hline \multirow[b]{2}{*}{ Activities } & \multirow[b]{2}{*}{ Target environments } & \multirow[b]{2}{*}{ Products and equipment } & \multicolumn{2}{|r|}{ Suggested use ${ }^{3}$} \\
\hline & & & Prevention & Outbreak control \\
\hline \multicolumn{5}{|c|}{ Targeting the mosquito larvae $^{1}$} \\
\hline $\begin{array}{l}\text { Environmental management } \\
\text { and source reduction }\end{array}$ & $\begin{array}{l}\text { artificial wetlands, hunting farms, } \\
\text { lagoons, recreational, rice fields, } \\
\text { irrigation canals, urban environments }\end{array}$ & $\begin{array}{l}\text { Ground equipment, excavators, } \\
\text { mowers, pumps }\end{array}$ & +++ & Part of IVM programme \\
\hline \multirow[t]{2}{*}{ Chemical } & \multirow[t]{2}{*}{$\begin{array}{l}\text { Breeding sites as specified in } \\
\text { the insecticide label }\end{array}$} & $\begin{array}{l}\text { According to } \mathrm{WHO} \text { guidelines } \\
\text { and EU regulations: }\end{array}$ & \multirow[t]{2}{*}{++} & \multirow[t]{2}{*}{ Part of IVM programme } \\
\hline & & $\begin{array}{l}\text { S-Methoprene, Diflubenzuron, } \\
\text { Pyriproxyfen, Triflumuron }\end{array}$ & & \\
\hline Biological & $\begin{array}{l}\text { artificial wetlands, lagoons, rice } \\
\text { fields, irrigation canals, urban } \\
\text { environments }\end{array}$ & $\begin{array}{l}\text { Gambusia (where allowed), native } \\
\text { fish species, Macrocyclops }\end{array}$ & ++ & Part of IVM programme \\
\hline \multirow[t]{2}{*}{ Microbial and others } & \multirow{2}{*}{$\begin{array}{l}\text { wetlands, lagoons, rice fields, } \\
\text { irrigation canals, urban } \\
\text { environments }\end{array}$} & $\begin{array}{l}\text { According to } \mathrm{WHO} \text { guidelines and } \\
\text { EU regulations }\end{array}$ & \multirow[t]{2}{*}{++} & \multirow[t]{2}{*}{ Part of IVM programme } \\
\hline & & $\begin{array}{l}\text { Bacillus thuringiensis israelensis, } \\
\text { Bacillus sphaericus, Spinosad }\end{array}$ & & \\
\hline Community participation & inhabited areas & $\begin{array}{l}\text { Insecticide formulations for } \\
\text { domestic use }\end{array}$ & + & Part of IVM programme \\
\hline \multicolumn{5}{|c|}{ Targeting the adult mosquitoes ${ }^{2}$} \\
\hline Aerial adulticide treatments & Outbreak area & Aerial ULV & Not allowed & $\begin{array}{c}\text { Not allowed (specific } \\
\text { exemption in extraordinary } \\
\text { cases only) }\end{array}$ \\
\hline $\begin{array}{l}\text { Ground adulticide } \\
\text { treatments (ULV or LV) }\end{array}$ & Outdoors, outbreak area & $\begin{array}{l}\text { According to } \mathrm{WHO} \text { guidelines } \\
\text { and EU regulations }\end{array}$ & $\begin{array}{c}\text { Not } \\
\text { suggested }\end{array}$ & ++ \\
\hline Mass trapping & domestic use in inhabited areas & $\begin{array}{l}\text { attractive traps selective for } \\
\text { mosquito }\end{array}$ & - & - \\
\hline $\begin{array}{l}\text { Personal protection } \\
\text { measures }\end{array}$ & $\begin{array}{l}\text { any environment during } \\
\text { mosquito activity peak in } \\
\text { case of West Nile virus risk }\end{array}$ & $\begin{array}{l}\text { mosquito screen over windows, } \\
\text { space or topical repellents, protective } \\
\text { clothes }\end{array}$ & +++ & +++ \\
\hline
\end{tabular}

${ }^{1}$ The suggested use of vector control methods targeting the mosquito larvae refers to the impact on the vector population. The impact in reducing the WNV transmission is not well known; ${ }^{2}$ The suggested use of vector control methods targeting the adult mosquitoes refers to the impact on WNV transmission; ${ }^{3}+++$ highly useful; ++ useful; + potentially useful in some circumstances; - currently no evidence of usefulness. IVM: integrated Vector management; ULV: Ultra Low Volume.

bio-control agents such as fishes and copepods or by allowing natural predators to colonise isolated water bodies by digging ditches to connect them [53-59]. This approach must be carefully evaluated in terms of environmental risk and the possible negative impact on biodiversity. Fish species such as Gambusia spp. are broad range predators and exotic to Europe. The "Habitats and Birds Directives" contain restrictions on the deliberate introductions of alien species into the wild and rearing and introduction of these species in water bodies is currently restricted in most countries. Predacious indigenous copepods such as Macrocyclops albidus may easily be reared and introduced in artificial containers where they reproduce and strongly reduce mosquito larval density [60]. They have limitations because they require good water quality and have been shown to be highly effective on Aedes, while only relatively effective on Culex species [58,61].

\section{Naturally derived products and microbial larval control}

Larval control by industrially produced bacteria is well developed because of the high efficacy combined with the selectivity of action which makes these products the best possible choice in terms of environmental impact. Several formulations based on Bacillus thuringiensis israelensis (B.t.i.) and Bacillus sphaericus (B.s.) bacteria formulations are available on the EU market or in the process of being marketed in the near future (see Biocides used in Europe section). The use of these products is usually allowed even in naturally protected areas. The main disadvantage is the short lasting activity which requires repeated applications. When bio-larvicide applications target large breeding areas (such as rice fields or wetlands) they may be performed by air (helicopter or fixed wings) following specific authorizations in exception of the 2002/2277 EU Parliament resolution. Relevant resistance phenomena have been evidenced following intensive utilization of B.s. against Culex species 
[62-64], while never observed on B.t.i. A new insecticide, Spinosad, derived via fermentation from the naturally occurring soil actinomycete, Saccharopolyspora spinosa, is also available in some countries and in the marketing process in others.

\section{Chemical larval control}

Direct larval control using chemical larvicides may be implemented using different products depending on the natural values of the target environment. Chemical larval control can only be done by ground application targeting previously mapped breeding sites. Four main active ingredients, all pertaining to the Insect Growth Regulators (IGRs) category, are currently available or under the revision process in the EU market: S-Methoprene, Diflubenzuron, Pyriproxyfen, Triflumuron [65]. Aerial application is not allowed following the adoption of the European Parliament resolution: "Towards a thematic strategy on the sustainable use of pesticides" (2002/2277 (INI)) (see Biocides used in Europe section).

\section{Community participation}

Culex control by community participation includes the elimination of breeding sites and larval control in private areas and can be part of the environmental management and source reduction approaches. Regular information campaigns may be organized targeting the most relevant citizen groups (e.g. farmers, land owners, scholars) aimed to promote the adoption of appropriate behaviour. These basic information campaigns should clearly consider the messages and the timing to obtain the best possible efficacy both in situation of possible and already ongoing outbreaks without losing effectiveness.

\section{Control measures targeting the adult mosquito}

In general adult mosquito control operations are aimed at the prompt reduction of adult mosquito density and longevity in a defined area in case of an outbreak. Adult control is not recommended as a routine method in outbreak prevention of WNV infection because outbreaks are currently largely unpredictable in time, space, and size. The environmental toxicity and broad action spectrum of the available insecticides for mosquito adult control implies that they can only be used in case of real need and focused on well-defined target areas. A well designed and managed active surveillance programme can be instrumental to define when adulticiding is appropriate (see Vector control decision making process section, Table 1). In any case measures of vector control to stop ongoing outbreaks of WNV infection should be implemented according to a pre-developed plan established as a public health measure by the sanitary authority. The plan should be technically detailed and responsibilities clearly defined.

\section{Adult control}

Adult control is considered the most convenient vector control approach during the outbreak phase because it has the capacity to promptly reduce infective mosquito females responsible for vectoring the disease as well as to reduce the mean longevity and the total reproduction capacity of local vector populations. The biocides and their application are strictly regulated by the EU and WHO provides guidelines on their use for public health purposes (see Biocides used in Europe section).

The current ground application technology for mosquito control mainly refers to equipment able to produce thermal or cold aerosols with particle dimensions of a defined range. It is considered that for mosquito adult control the best efficacy in terms of mortality is achieved when droplet diameter is in the range 5-30 $\mu \mathrm{m}$ (the best droplet size must be defined more precisely according to parameters such as formulation type and concentration, application equipment, environmental condition, habitat type, target species sensitivity) [66-71]. Ultra Low Volume (ULV) application is defined as the minimum effective volume of the formulated product without any further dilution (0.6-18 l/h). While Low Volume (LV) (18-60 l/h) and High Volume (HV) (>150 l/h) require the formulation being diluted before use.

There is no vector density threshold to guide decisions about the degree of vector population suppression that must be attained, or for how long this suppression must be maintained to reduce human disease transmission [38]. Through mathematical modelling it has been suggested that it would be appropriate to focus the vector control activities late in the season to target overwintering mosquitoes when temperatures are dropping [72]. The practical implications of a vector control program targeting overwintering mosquito females need further evaluation.

\section{Mass trapping}

A number of traps have been developed to attract, catch and kill large numbers of mosquitoes, thus removing them from the target area. This technology is developing rapidly and there is considerable variability in the way these traps function $[73,74]$. Studies set-up to determine the real level of protection provided by these traps in the area they possibly cover showed low effectiveness [75,76].

\section{Personal protection methods}

Personal protection methods from mosquito bites include the use of space or topical repellents, the installation of mosquito screens over windows, wearing protective clothes (such as long sleeves and long pants), the adoption of preventative behaviour useful to help to avoid or reduce exposure to mosquito bites (i.e. limit 
outdoor activities when mosquitoes are most active), and mosquito proof homes. The effectiveness of personal protection methods in reducing the risk of acquiring WNV infection has been demonstrated by Loeb et al. [77] in Ontario, Canada. Between the different available tools for self-protection, repellents play an important role as they protect people when outdoors for normal activities. The most effective repellent substances are: DEET (N,N Diethyl Toluamide), Picaridin (1-(1methylpropylcarbonyl)2-(hydroxyethyl)-piperidine), also known as KBR, and IR3535. Recently, various essential oils have been proposed as insect repellents, but their protection against anthropophilic species is considered low [78-82]. A number of studies have demonstrated that electronic mosquito repellers are ineffective and that some of them could even increase the biting frequency of mosquitoes [83,84].

To favour a large adoption of personal protection methods specific information campaigns must be conducted. These campaigns are not suggested as a routine preventative method for outbreaks of WNV infection, but they need to be connected to an active surveillance system in order to be activated only in case of real risk (see Vector control decision making process section).

\section{Biocides used in Europe}

The biocides that can be used for larval and adult mosquito control are based on the active ingredients covered in the review being carried out under the Biocides Directive 98/8/EC (second phase of the 10-year work programme referred to in Article 16), Commission Regulation (EC) No 1451/2007 of 4 December 2007 and more recently by the Biocides Regulation 528/2012. The objective of the new Regulation is to improve the functioning of the EU internal market in biocidal products whilst ensuring a high level of environmental and human health protection. Some concerns have been raised on the possibility that following the procedure few products will available for vector control thus weakening our capacity to protect communities from vector-borne diseases.

WHO through the WHO Pesticide Evaluation Scheme (WHOPES) collects, consolidates, evaluates and disseminates information and guidelines on the use of pesticides for public health. Updated information can be found on the website (http://www.who.int/whopes/en/).

The organization of mosquito control refers to ground application as the aerial distribution of toxic insecticides is strictly forbidden following the European Parliament resolution 2002/2277. In case of an ongoing large epidemic there might be an emergency exception under the responsibility of regional or country authorities. As an example, in Greece, experimental aerial treatments using a helicopter equipped with ULV nozzles to spray pyrethroids (Deltamethrin and D-Phenothrin) against mosquitoes have been recently conducted during the outbreak of WNV infection [85].

For mosquito larval control five active ingredients are currently available or under the revision process, namely S-Methoprene, Diflubenzuron, Pyriproxyfen, Triflumuron, Spinosad [65]. Several formulations of microbial larvicides based on Bacillus thuringiensis israelensis are available on the EU market (liquid, powder, granular, briquette) [86]. Bacillus sphaericus formulations are present in some countries (i.e. France, Germany), while in the process of being marketed in the near future in other countries.

The main active ingredients for adult control belong to the pyrethrin and pyrethroids group. These compounds have good safety margins in terms of acute toxicity for warm blooded animals but are toxic for non target insect species and aquatic organisms [87-90]. Possible long term effects and cumulative effects are much more complex to establish.

\section{Impact and cost-benefit of vector management on WNV transmission}

Available data on the impact of vector control on WNV transmission is available from the USA showing both failures and successes (summarised in Table 2), while documented examples for Europe are not available. In general, single application for adult control has been shown to have a transient effect and, in the event of an epidemic, multiple sequential treatments may be required to decrease vector abundance to a level that will stop transmission [Table 2 and [91,92]]. As a general opinion shared by US colleagues repeated aerial treatments seem to be more effective in reducing WNV circulation than ground application because the capacity to rapidly cover large areas. Effective surveillance must be maintained during vector control activities to determine if and when re-treatment is required to maintain suppression of the vector populations. Vegetation may have a negative effect on ULV treatment efficacy by filtering the aerosol leading to a reduction in the amount of pesticide available to impact the mosquito, and by reducing wind speed in the canopy thus reducing aerosol dispersion.

Considering the efficacy of personal protection measures in reducing the risk of acquiring WNV infection Loeb [77], working in Ontario, Canada, demonstrated that the adoption of $\geq 2$ personal protective behaviour attitude (such as avoidance of exposure to mosquitoes, wearing long sleeves and pants, using mosquito repellent) reduced the risk of WNV infection by half. Averett et al. [102] evaluated the $2003 \mathrm{WNV}$ public education campaign in Kansas. Even if the campaign achieved widespread awareness among the public, people's compliance to use protective measures was low most probably because of a low risk perception of WNV infection. The messages were most effectively delivered through television, newspapers 
Table 2 Examples from the USA on the use of adult mosquito management in the control of outbreaks of WNV infection

\begin{tabular}{llll}
\hline Study & Observed efficacy & Reference \\
\hline Louisiana & $\begin{array}{l}\text { This study calculated an 86\% decrease (compared with a 5-year average) in WNV mosquito vector species in 2002 resulting } \\
\text { from increasing control efforts (aerial and ground ULV with Naled (1,2-dibromo-2,2-dichloroethyl dimethyl phosphate) over } \\
\text { a 4-month period in St. Tammany Parish, Louisiana. }\end{array}$ & [93]
\end{tabular}

Florida This study estimated a seasonal mean 64.1\% Culex nigripalpus density reduction following emergency aerial sprays with Naled in 26 Florida counties during 2004, in response to several hurricanes.

Boston Poor efficacy of ground ULV treatments with Resmethrin against $C X$. pipiens and $C x$. restuans in the Boston area showed that the aerosol plume delivered from the road failed to contact the target mosquitoes because it was blocked by the vegetation. Therefore, the application was unable to reduce transmission of WNV.

Kentucky The University of Kentucky evaluated the efficacy of professional application of bifenthrin and lambda-cyhalothrin as barrier treatments with backpack mist blower directed to all vegetative surfaces up to the height of $3 \mathrm{~m}$. Residual efficacy in reducing adult mosquito populations was studied at 24 residential properties (eight replications by three treatments). Mosquito populations were measured on each property by using five methods: $\mathrm{CO}_{2}$-baited CDC light traps (without a light), human landing rates, CDC gravid traps, ovitraps, and sweep nets. Populations were monitored weekly for two weeks before treatment and eight weeks post-treatment. Additionally, to confirm residual efficacy of each insecticide, a randomly treated leaf underwent a no-choice bioassay with laboratory-reared Ae. albopictus. Trap collections indicate Ae. albopictus and Cx. pipiens as the most abundant species in the area. Both insecticides significantly reduced Ae. albopictus density in comparison with the untreated control areas (85.1-89.5\% reduction), and Ae. albopictus bioassay showed significant residual efficacy for both insecticides up to six weeks post-treatment. In contrast, Culex spp. were not reduced by either insecticides. The study seems to therefore indicate that barrier sprays applied to low-lying vegetation do not properly target adult daytime resting sites for Culex mosquitoes but that they can reduce Aedes mosquitoes. Perhaps Culex spp. abundance may be reduced by treating upper tree canopies.

California In California, in 2004-2005, a program was implemented to control the amplification and dispersal of WNV using sequential ground ULV applications of Pyrenone ${ }^{\oplus} 25-5$ (Insecticide containing Pyrethrins (5.0\%) and Piperonyl Butoxide (25.0\%)). Local treatments were started one month after the initial detection. Evaluations indicated that while the treatments were effective in reducing vector abundance, they had little effect on virus transmission, and WNV was dispersing throughout the area.

Sacramento Carney et al. determined the efficacy of the aerial treatments with pyrethrins combined with piperonyl butoxide (PBO) on WNV transmission in Sacramento county during the 2005 epidemic. No human cases occurred in the treated area after repeated treatments (number of treatments not specified), compared with 18 cases in the untreated area. Consequently, they considered the emergency aerial spray to be effective in reducing both mosquito populations and WNV cases.

California In the Coachella Valley good results were achieved with early season treatment in mid-April immediately following the first detection of WNV.

California In Sacramento County, an aerial distribution of Evergreen EC 60-6 (insecticide containing Pyrethrins (6.00\%) and Piperonyl butoxide (60.00\%)) over approximately $215 \mathrm{~km}^{2}$ obtained a significant decrease in the abundance of both $C x$. tarsalis and Cx. pipiens, as shown by pre- and post-trapping realized inside and outside the spray zone.

New York Controlling mosquito populations at the end of the season, before Culex females enter refuges, appeared to be an effective way to force declines in the virus circulation

California This study examined the efficacy of the 2005 emergency aerial spray in Sacramento County, which used pyrethrins to control adult mosquitoes. An unsprayed area within the county was used as the control, showing a total decrease in $C x$. pipiens and CX. tarsalis, of $57.5 \%$, compared with the pre-spray population in the treated area. They also observed a decrease in WNV infection rates in collected mosquitoes from 6.7/1,000 in the untreated areas to 3.9/1,000 in the treated areas.

Illinois In the 2005 the city of Chicago used ground ULV treatments of sumithrin (ANVIL $10+10$ at the dose of $1.36 \mathrm{~g} / \mathrm{ha}$ ), in areas with high WNV infection rates among Culex mosquitoes ( $>5$ infected mosquitoes/1000). Gravid traps at 87 sites were used for monitoring. Two sequential treatments in weeks 31 and 32 decreased mean mosquito density by 54\% (from 2.5 to 1.1 mosquitoes per trap-day), whereas mosquito density increased from 1.3 to 3.3 mosquitoes per trap-day at the non-sprayed sites. The difference between these changes in mosquito density was statistically significant. While other two sequential adulticide treatments in weeks 34 and 35 had no effect on mosquito density (probably because it was late in the season and the mosquitoes were presumably entering diapause and less active). Overall, there was significant decrease in mosquito density at the trap sites treated in all 4 weeks (weeks 31, 32, 34, and 35), while no significant effect was observed following single applications. Maximum likelihood estimates (MLE) of infection rate estimates varied independently of adulticide treatments, suggesting that the adulticide treatments had no direct effect on MLE. In general gravid trap counts were very low, which was probably due to large numbers of alternative oviposition sites, especially catch basins competing with the gravid traps.

and word-of-mouth, whereas passing messages through healthcare providers, veterinarians, magazines, and the internet were less successful. Brochures were least successful, indicating that they may be ineffective for this type of communication. None-native English speakers were less informed than native ones.

A cost-effectiveness analysis of vector control generically starts from a problem and presuppose an analysis of costs and effectiveness of each alternative solution [103]. The little scientific information focused on cost-benefit analysis in vector control targeted to WNV transmission comes from the US, following the large WNV epidemic the country experienced from 1999. The impact of WNV infection in the US was large, reaching a peak in the 2003 when 9,862 human cases (264 deaths) were registered (http://www.cdc. gov/ncidod/dvbid/westnile/surv\&control_archive.htm). 
Zohrabian et al. [104] estimated the economic impact of the outbreak of WNV infection in 2002 in Louisiana, which resulted in 329 cases with 24 deaths. They considered the period June 2002-February 2003 (therefore long term costs were not considered), and included costs related to total medical care, productivity loss, public health department state activities, and vector control. Total epidemic costs were estimated as $\approx 20.14$ million\$ (including 9.2 million\$ for mosquito control and public health agency costs) equal to 61,215 \$/case. In 2005, an outbreak of WNV infection occurred in Sacramento County, California, where 163 human cases were reported. In response to WNV surveillance indicating increased WNV activity, the Sacramento-Yolo Mosquito and Vector Control District conducted an emergency aerial spray by pyrethrins for six nights on an area of $\approx 477 \mathrm{~km}^{2}$. The economic impact of the outbreak (including medical cost to treat cases and patients' productivity loss) has been estimated as $\approx \$ 2.28$ million (equal to $13,987 \$ /$ case). Vector control cost was estimated as $\approx \$ 701,790$. A cost-benefit analysis indicated that only 15 cases of WNV neuroinvasive disease would need to be prevented to make the emergency spray cost-effective [105].

\section{Vector control decision making process}

Prevention and control of WNV infection should be based on an integrated preparedness plan taking into consideration surveillance, communication, IVM activities, intersectoral collaboration, and evaluation. The activation of the plan should be based on the surveillance data from the four possible basic indicators: mosquitoes, birds, horses and humans. The main parameters to be considered are: the level of virus activity in the area estimated by the infection rate in Culex mosquitoes, the percentage viremic birds, the equine cases, or recent seroconversions in sentinel birds or equines; the seasonal period when WNV activity is first detected since the earlyseason detection of WNV activity appears to be correlated with increased risk of human cases later in the season, whereas late-season detection of WNV activity may not indicate a real human risk. In this framework it is considered that the risk of tangential transmission exists when the surveillance activities show an increase in the circulation of the virus. The complex epidemiology of WNV infections requires that the surveillance activities are well coordinated and progressively improved based on field evidence and proper evaluation. A baseline scheme to assist an evidence based decision making process is depicted below. Difficulties in early estimation of the outbreak size in time and space complicates the implementation of adapted vector control measures, hence the need to elaborate models to achieve a more precise epidemiological forecast, allowing more effective and cost-benefit appropriate decisions (Table 3 ).

\section{Conclusions}

Most of the available data on WNV vector control methods refer to North America, where, following the introduction of the virus in 1999 and its rapid spread through the country, an impressive amount of scientific investigation as well as organized plans and implementation of vector control activities have been developed. The reason why such an effort has never been made in Europe has obviously come from the smaller impact the WNV infection had on public health, with sporadic incursions in sensitive areas and long periods of silence and non-evident circulation. This situation seems to have changed recently with several EU countries affected in consecutive years. The US experience showed that, when applied with appropriate methodologies and resources, vector control measures such as adult control may reduce the outbreak size. Multiple sequential treatments may be necessary to reduce Culex female density to a level where reduction of WNV infection may be observed. If a large area is involved it becomes quite difficult to organize an effective adult control program using ground application only. The real effectiveness of mosquito larval control in preventing or reducing the risk for WNV human cases is a logical assumption but remains to be demonstrated. While preferable to adult control from the environmental points of view, larval control might not be as effective as expected due to density dependent phenomena and because it has no influence on longevity of infective mosquito females. Based on the available evidence an overview of the use of the currently existing vector control methods is presented in Table 1. Further studies are needed in the EU to assess the value of each method to prevent and control outbreaks of WNV infection and to assess the best use in time and space (e.g. by the identification of hot spot areas particularly favourable for the WNV amplification early in the season). The proposed vector control decision making process, in line with ECDC's West Nile risk assessment tool [107], aims at supporting the rational choice of the control methods but warrants further validation and refinement based on experiences from outbreak control.

The extrapolation of information produced in North America to Europe might be limited because of the seemingly lower level of WNV transmission in the European region probably due to the long-time exposure of wild bird populations resulting in an ecosystem that is less suitable for large outbreaks. Additionally, the diversity of the susceptible bird fauna and of the vector species involved in the enzootic and tangential transmission in Europe makes WNV transmission remarkably different with the US. Aerial insecticide applications being largely adopted in the US are basically not allowed in the EU. Hence, the cost-benefit of vector control in the US 
Table 3 Vector control decision making process: recommended response for the different risk levels

\begin{tabular}{|c|c|c|c|c|}
\hline Risk area ${ }^{1}$ & $\begin{array}{l}\text { Risk } \\
\text { level }\end{array}$ & $\begin{array}{l}\text { Probability of } \\
\text { human outbreak }\end{array}$ & Description & Recommended response \\
\hline Predisposed & 1 & Unknown & $\begin{array}{l}\text { Ecological condition suitable to WNV } \\
\text { circulation AND past evidences of } \\
\text { WNV circulation }\end{array}$ & Consider drafting WNV preparedness plan \\
\hline \multirow[t]{3}{*}{ Imperilled } & \multirow[t]{3}{*}{2} & \multirow[t]{3}{*}{ Unknown } & $\begin{array}{l}\text { Ecological condition suitable to } \\
\text { WNV circulation }\end{array}$ & $\begin{array}{l}\text { Develop WNV preparedness plan, including } \\
\text { surveillance activities and an integrated vector } \\
\text { control plan }\end{array}$ \\
\hline & & & \multirow[t]{2}{*}{ AND past evidences of WNV circulation } & $\begin{array}{l}\text { Allocate resources necessary to enable } \\
\text { emergency response }\end{array}$ \\
\hline & & & & $\begin{array}{l}\text { Implement larval control as part of the } \\
\text { integrated vector control in case of WNV } \\
\text { circulation in previous year }\end{array}$ \\
\hline \multirow[t]{3}{*}{ Imperilled } & \multirow[t]{3}{*}{$3 a$} & \multirow[t]{3}{*}{ Low } & \multirow{3}{*}{$\begin{array}{l}\text { Current surveillance findings (i.e. mosquito } \\
\text { or birds screening) indicating WNV epizootic } \\
\text { activity in the area, in the second part of } \\
\text { the season (August-September-October) }\end{array}$} & As in risk level 2 \\
\hline & & & & $\begin{array}{l}\text { AND Implement public education programs } \\
\text { focused on risk potential, personal protection, } \\
\text { and emphasizing residential source reduction }\end{array}$ \\
\hline & & & & Vector control focuses on larval control \\
\hline \multirow[t]{4}{*}{ Imperilled } & \multirow[t]{4}{*}{$3 b$} & \multirow[t]{4}{*}{ Low to moderate } & \multirow{4}{*}{$\begin{array}{l}\text { Current surveillance findings (i.e. mosquito } \\
\text { or birds screening) indicating WNV } \\
\text { epizootic activity in the area, in the first } \\
\text { part of the season (May-June-July) }\end{array}$} & As in risk level 3a \\
\hline & & & & AND increase entomological and bird surveillance \\
\hline & & & & $\begin{array}{l}\text { AND increase effort for public information on } \\
\text { personal protection and continued source reduction }\end{array}$ \\
\hline & & & & $\begin{array}{l}\text { AND If surveillance indicates virus circulation is } \\
\text { increasing initiate ground adult control in areas at } \\
\text { high risk for humans or in hot spot sites (if known) }\end{array}$ \\
\hline \multirow[t]{2}{*}{ Imperilled } & \multirow[t]{2}{*}{4} & \multirow[t]{2}{*}{ High } & \multirow{2}{*}{$\begin{array}{l}\text { WNV specific lgM detected in local non } \\
\text { vaccinated horse(s) or WNV isolated } \\
\text { from local horse. }\end{array}$} & As in risk level $3 b$ \\
\hline & & & & $\begin{array}{l}\text { If surveillance indicates virus circulation is increasing } \\
\text { initiate ground adult control in areas at high risk for } \\
\text { humans or in hot spot sites (if known) }\end{array}$ \\
\hline \multirow[t]{5}{*}{ Affected } & \multirow[t]{5}{*}{5} & \multirow{5}{*}{$\begin{array}{l}\text { ongoing outbreak, } \\
\text { uncertainty about size }\end{array}$} & \multirow{5}{*}{$\begin{array}{l}\text { at least one human case detected } \\
\text { (i.e. probable or confirmed human case } \\
\text { according to EU case definition) }\end{array}$} & Response as in level 4 \\
\hline & & & & $\begin{array}{l}\text { AND intensify ground adult mosquito control with } \\
\text { multiple applications in areas of high risk of human cases }\end{array}$ \\
\hline & & & & AND enhance risk communication \\
\hline & & & & $\begin{array}{l}\text { AND monitor efficacy of spraying on target mosquito } \\
\text { populations }\end{array}$ \\
\hline & & & & $\begin{array}{l}\text { AND in case a large area is involved coordinate the } \\
\text { program by an emergency unit with all authorities } \\
\text { involved }\end{array}$ \\
\hline
\end{tabular}

${ }^{1}$ Nomenclature according to [106].

compared to the EU might be very different and requires a careful specific evaluation. Therefore, there is an urgent need to analyse the European experiences on the prevention and control of outbreaks of WNV infection in order to optimize resources while keeping the risk of acquiring the infection at an acceptable level.

To be effective, vector control programs require a strong organisational backbone and co-ordination between the different stakeholders from the central to the community level relying on a previously defined plan, skilled technicians and operators, appropriate equipment, and sufficient financial resources. The permanent allocations of resources on an issue which is largely unpredictable in space and time, with elapsing periods between outbreaks that may last for years, could be difficult to sustain and justify but is needed to develop proper preparedness and response activities.

\section{Abbreviations}

EU: European Union; B.t.i.: Bacillus thuringiensis israelensis; B.S.: Bacillus sphaericus; IVM: Integrated vector management; PBO: Piperonyl butoxide; ULV: Ultra low volume; WNV: West Nile virus.

\section{Competing interests}

The authors declare that they have no competing interests.

\section{Authors' contributions}

RB carried out the literature search and prepared the first draft of the manuscript under the contract ECD.3191 financed by the ECDC. WVB contributed to writing the paper and $\mathrm{HZ}$ and $\mathrm{WVB}$ critically revised the manuscript. All authors read and approved the final submitted version. 


\section{Authors' information}

$\mathrm{RB}$ is a medical entomologist currently working at the Centro Agricoltura Ambiente "G.Nicoli" in Italy, where he is the director of the Medical and Veterinary Entomology Department.

$\mathrm{HZ}$ is a virologist working at the European Centre for Disease Prevention and Control where he is head of the Emerging and Vector-borne Diseases programme.

WVB is a medical entomologist working at the European Centre for Disease Prevention and Control.

\section{Acknowledgements}

A number of colleagues kindly advised us and provided information useful during the preparation of this paper, and we would like to thank namely: Paulo Almeida, Carles Aranda, David Brown, Jonathan Day, Enkelejda Dikoll Velo, Luciano Donati, Roger Eritja, Raul Escosa, Eleonora Flacio, Christophe Lagneau, Vicki Kramer, Branka Lothrop, Jan O. Lundström, Eduard Marquès i Mora, Jolyon Medlock, Roger Nasci, Bill Reisen, Frantisek Rettich, Elton Rogozi, Ernst-Jan Scholte, Mauro Tonolla, Rodolfo Veronesi, while apologizing for any possible missing names. This work was financed by the ECDC specific contract ECD.3191.

\section{Author details}

'Centro Agricoltura Ambiente "G.Nicoli", Via Argini Nord 3351, Crevalcore 40014, Italy. ${ }^{2}$ European Centre for Disease Prevention and Control, Stockholm, Sweden.

Received: 6 February 2014 Accepted: 13 June 2014

Published: 11 July 2014

\section{References}

1. Hurlbut HS, Rizk F, Taylor RM, Work TH: A study of the ecology of West Nile virus in Egypt. Am J Trop Med Hygiene 1956, 5(4):579-620.

2. Zeller HG, Schuffenecker I: West Nile virus: an overview of its spread in europe and the Mediterranean Basin in contrast to its spread in the Americas. Eur J Clin Microbiol 2004, 23(3):147-156.

3. Petersen LR, Carson PJ, Biggerstaff BJ, Custer B, Borchardt SM, Busch MP: Estimated cumulative incidence of West Nile virus infection in US adults, 1999-2010. Epidemiol Infect 2013, 141:591-595.

4. Ladbury GA, Gavana M, Danis K, Papa A, Papamichail D, Mourelatos S, Gewehr S, Theocharopoulos G, Bonovas S, Benos A, Panagiotopoulos T: Population seroprevalence study after a west nile virus lineage 2 epidemic, Greece, 2010. Plos One 2013, 8(11):e80432.

5. Anderson JF, Main AJ: Importance of vertical and horizontal transmission of West Nile virus by Culex pipiens in the northeastern United States. $J$ Infect Dis 2006, 194(11):1577-1579.

6. Andreadis TG, Armstrong PM, Bajwa WI: Studies on hibernating populations of Culex pipiens from a West Nile virus endemic focus in New York City: parity rates and isolation of West Nile virus. J Am Mosa Contr Assoc 2010, 26(3):257-264.

7. Bugbee LM, Forte LR: The discovery of West Nile virus in overwintering Culex pipiens (Diptera : Culicidae) mosquitoes in Lehigh County, Pennsylvania. J Am Mosa Contr Assoc 2004, 20(3):326-327.

8. Nasci RS, Savage HM, White DJ, Miller JR, Cropp BC, Godsey MS, Kerst AJ, Bennett P, Gottfried K, Lanciotti RS: West Nile virus in overwintering Culex mosquitoes, New York City, 2000. Emerg Infect Dis 2001, 7(4):742-744.

9. Reisen WK, Fang Y, Lothrop HD, Martinez VM, Wilson J, O'Connor P, Carney R, Cahoon-Young B, Shafii M, Brault AC: Overwintering of West Nile virus in southern California. J Med Entomol 2006, 43(2):344-355.

10. Tesh RB, Parsons R, Siirin M, Randle Y, Sargent C, Guzman H, Wuithiranyagool T, Higgs S, Vanlandingham DL, Bala AA, Haas K, Zerinque B: Year-round West Nile virus activity, Gulf Coast region, Texas and Louisiana. Emerg Infect Dis 2004, 10(9):1649-1652.

11. Hubalek Z, Halouzka J: West Nile fever - a reemerging mosquito-borne viral disease in Europe. Emerg Infect Dis 1999, 5(5):643-650

12. Tsai TF, Popovici F, Cernescu C, Campbell GL, Nedelcu NI, Team I: West Nile encephalitis epidemic in southeastern Romania. Lancet 1998, 352(9130):767-771.

13. ECDC: Reported cases of West Nile fever for the EU and neighbouring countries. Transmission season 2013 and previous transmission seasons; latest update: 06/11/2013. In http://ecdc.europa.eu/en/healthtopics/ west_nile_fever/West-Nile-fever-maps/pages/index.aspx.
14. Calistri P, Giovannini A, Hubalek Z, lonescu A, Monaco F, Savini G, Lelli R: Epidemiology of west nile in europe and in the mediterranean basin. Open Virol J 2010, 4:29-37.

15. Stiasny K, Aberle SW, Heinz FX: Retrospective identification of human cases of West Nile virus infection in Austria (2009 to 2010) by serological differentiation from Usutu and other flavivirus infections. Euro Surveill 2013, 18(43):20614.

16. Merdic E, Peric L, Pandak N, Kurolt IC, Turic N, Vignjevic G, Stolfa I, Milas J, Bogojevic MS, Markotic A: West Nile virus outbreak in humans in Croatia, 2012. Coll Antropol 2013, 37(3):943-947.

17. Hubalek Z, Halouzka J, Juricova Z: West Nile fever in Czechland. Emerg Infect Dis 1999, 5(4):594-595.

18. Hubalek Z, Lukacova L, Halouzka J, Sirucek P, Januska J, Precechtelova J, Prochazka P: Import of West Nile virus infection in the Czech Republic. Eu J Epidemiol 2006, 21(4):323-324.

19. Del Giudice P, Schuffenecker I, Vandenbos F, Counillon E, Zeller H: Human West Nile virus, France. Emerg Infect Dis 2004, 10(10):1885-1886.

20. Papa A, Danis K, Baka A, Bakas A, Dougas G, Lytras T, Theocharopoulos G, Chrysagis D, Vassiliadou E, Kamaria F, Liona A, Mellou K, Saroglou G, Panagiotopoulos T: Ongoing outbreak of West Nile virus infections in humans in Greece, July - August 2010. Euro Surveill 2010, 15(34):19644

21. Glavits R, Ferenczi E, Ivanics E, Bakonyi T, Mato T, Zarka P, Palya V: Co-occurrence of West Nile fever and circovirus infection in a goose flock in Hungary. Avian Pathol 2005, 34(5):408-414.

22. Rizzo C, Vescio F, Declich S, Finarelli AC, Macini P, Mattivi A, Rossini G, Piovesan C, Barzon L, Palu G, Gobbi F, Macchi L, Pavan A, Magurano F, Ciufolini MG, Nicoletti L, Salmaso S, Rezza G: West Nile virus transmission with human cases in Italy, August-September 2009. Euro Surveill 2009, 14(40):19353.

23. Connell J, McKeown P, Garvey P, Cotter S, Conway A, O'Flanagan D, O'Herlihy BP, Morgan D, Nicoll A, Lloyd G: Two linked cases of West Nile virus (WNV) acquired by Irish tourists in the Algarve, Portugal. Euro Surveill 2004, 8(32):2517.

24. Campbell GL, Ceianu CS, Savage HM: Epidemic West Nile encephalitis in Romania: waiting for history to repeat itself. Ann N Y Acad Sci 2001, 951:94-101.

25. Popovic N, Milosevic B, Urosevic A, Poluga J, Lavadinovic L, Nedelijkovic J, Jevtovic D, Dulovic O: Outbreak of West Nile virus infection among humans in Serbia, August to October 2012. Euro Surveill 2013, 18(43):20613.

26. Bofill D, Domingo C, Cardenosa N, Zaragoza J, de Ory F, Minquell S, Sanchez-Seco MP, Dominguez A, Tenorio A: Human West Nile virus infection, Catalonia, Spain. Emerg Infect Dis 2006, 12(7):1163-1164.

27. Kaptoul D, Viladrich PF, Domingo C, Niubo J, Martinez-Yelamos S, De Ory F Tenorio A: West Nile virus in Spain: report of the first diagnosed case (in Spain) in a human with aseptic meningitis. Scand J Infect Dis 2007, 39(1):70-71.

28. Hubalek Z: European experience with the West Nile virus ecology and epidemiology: could it be relevant for the new world? Viral Immunol 2000, 13(4):415-426.

29. Esteves A, Almeida APG, Galao RP, Parreira R, Piedade J, Rodrigues JC, Sousa CA, Novo MT: West Nile virus in Southern Portugal, 2004. Vector-Borne Zoon Dis 2005, 5(4):410-413.

30. Almeida APG, Galao RP, Sousa CA, Novo MT, Parreira R, Pinto J, Piedade J, Esteves A: Potential mosquito vectors of arboviruses in Portugal: species, distribution, abundance and West Nile infection. T Roy Soc Trop Med H 2008 , 102(8):823-832.

31. Calzolari M, Bonilauri P, Bellini R, Albieri A, Defilippo F, Maioli G, Galletti G, Gelati A, Barbieri I, Tamba M, Lelli D, Carra E, Cordioli P, Angelini P, Dottori M: Evidence of simultaneous circulation of West Nile and usutu viruses in mosquitoes sampled in Emilia-Romagna Region (Italy) in 2009. Plos One 2010, 5(12):14324.

32. Reusken CBEM, de Vries A, Buijs J, Braks MAH, den Hartog W, Scholte EJ: First evidence for presence of Culex pipiens biotype molestus in the Netherlands, and of hybrid biotype pipiens and molestus in northern Europe. J Vector Ecol 2010, 35(1):210-212.

33. Chaskopoulou A, Dovas Cl, Chaintoutis SC, Kashefi J, Koehler P Papanastassopoulou M: Detection and early warning of West Nile Virus circulation in Central Macedonia, Greece, using sentinel chickens and mosquitoes. Vector-Borne Zoon Dis 2013, 13(10):723-732

34. Mouchet J, Rageau J, Laumond C, Hannoun C, Beytout D, Oudar J, Corniou B, Chippaux A: [Epidemiology of West Nile virus: study of a focus in 
Camargue. V. The fector: Culex modestus Ficalbi Diptera; Culicidae]. Ann Inst Pasteur 1970, 118(6):839-855.

35. Zeller H, Lenglet A, Van Bortel W: West Nile virus: the need to strengthen preparedness in Europe. Euro Surveill 2010, 15(34):19647.

36. WHO: WHO position statement on integrated vector management. Geneva: World Health Organization; 2008

37. EU: West Nile virus and blood safety introduction to a preparedness plan. Europe: European Commission; 2012.

38. CDC: Epidemic/Epizootic West Nile Virus in the United States: Guidelines for Surveillance, Prevention, and Control. Fort Collins, Colorado: Fort Collins: U.S Department of Health and Human Services, Public Health Service, Centers for Disease Control and Prevention, National Center for Infectious Diseases, Division of Vector-Borne Infectious Diseases; 2003. 3rd Revision.

39. Connelly CR, Carlson DB: Florida Mosquito Control: The state of the mission as defined by mosquito controllers, regulators, and environmental managers. Florida: Vero Beach, FL: University of Florida, Institute of Food and Agricultural Sciences, Florida Medical Entomology Laboratory; 2009.

40. Brown EG: California mosquito-borne virus surveillance \& response plan. California: California Department of Public Health Mosquito \& Vector Control Association of California University of California; 2011.

41. Dale P: Runnelling procedures manual (including environmental management). In Report prepared for Redland Shire Council by Pat Dale Faculty of Environmental Sciences Griffith University, August 1997; 1997.

42. Knight RL, Walton WE, O'Meara GF, Reisen WK, Wass R: Strategies for effective mosquito control in constructed treatment wetlands. Ecol Eng 2003, 21(4-5):211-232.

43. Warchot A, Whelan P: Constructed Wetlands in the Northern Territory: guidelines to prevent mosquito breeding. Casuarina NT: Medical Entomology Branch, Centre for Disease Control, Department of Health and Families Services; 2008:0811. PO Box 40596.

44. Collins FH, Washino RK: The effects of irrigation water source and crop rotation on the abundance of Culex tarsalis in California rice fields. Proc Californian Mos Vector Contr Assoc 1980, 48:103-108.

45. Chambers DM, Steelman CD, Schilling PE: The effect of cultural practices on mosquito adundance and distribution in the Louisiana riceland ecosystem. Mosa News 1981, 41:233-240.

46. Keiser J, Maltese MF, Erlanger TE, Bos R, Tanner M, Singer BH, Utzinger J: Effect of irrigated rice agriculture on Japanese encephalitis, including challenges and opportunities for integrated vector management. Acta Trop 2005, 95(1):40-57.

47. Lawler SP, Dritz DA: Effects of rice straw and water management on riceland mosquitoes. J Med Entomol 2006, 43(5):828-832.

48. Ishii T, Sohn SR: Highly polluted larval habitats of the Culex pipiens complex in central Sweden. J Am Mosq Contr Assoc 1987, 3(2):276-281.

49. Sanford MR, Chan K, Walton WE: Effects of inorganic nitrogen enrichment on mosquitoes (Diptera : Culicidae) and the associated aquatic community in constructed treatment wetlands. J Med Entomol 2005, 42(5):766-776.

50. Chaves LF, Keogh CL, Vazquez-Prokopec GM, Kitron UD: Combined sewage overflow enhances oviposition of Culex quinquefasciatus (Diptera: Culicidae) in urban areas. J Med Entomol 2009, 46(2):220-226.

51. Santha CR, Martyn RD, Neill WH, Strawn K: Control of submersed weeds by grass carp in waterlily production ponds. J Aquat Plant Manage 1994, 32:29-33.

52. FAO: Interactions between fish and aquatic macrophytes in inland waters. Queensland, Australia: Food and Agriculture Organization of the United Nations; 2000

53. WHO: Update of annotated bibliography of papers relating to the control of moquitoes by the use of fish for the years 1965-1981. Geneva: WHO; 1985.

54. Bellini R, Veronesi R, Rizzoli M: Efficacy of various fish species (Carassius auratus (L), Cyprinus carpio (L), Gambusia affinis (Baird and Girard) in the control of rice field mosquitoes in northern Italy. Bull Soc Vector Ecol 1994, 19(2):87-99.

55. WHO: The use of fish for mosquito control. Geneva: WHO; 2003.

56. Haq S: Developing larvivorous fish network for mosquito control in urban areas: a case study. ICMR Bull 2003, 33(7):69-73.

57. FAO: In Culture of fish in rice fields. Edited by Halwart M, Gupta VM. Rome: $\mathrm{FAO} ; 2004$.

58. Kay B, Vu SN: New strategy against Aedes aegypti in Vietnam. Lancet 2005, 365(9459):613-617.

59. Hurst $T$, Ryan $P$, Brown $M$, Kay B: Fushing for a mosquito control agent. Arbovirus Res Aust 2005, 9:143-147.
60. Marten GG, Nguyen M, Mason BJ, Ngo G: Natural control of Culex quinquefasciatus larvae in residential ditches by the copepod Macrocyclops albidus. J Vector Ecol 2000, 25(1):7-15.

61. Soumare MKF, Cilek JE: The effectiveness of Mesocyclops longisetus (Copepoda) for the control of container-inhabiting mosquitoes in residential environments. J Am Mosq Contr Assoc 2011, 27(4):376-383.

62. Chevillon C, Bernard C, Marquine M, Pasteur N: Resistance to Bacillus sphaericus in Culex pipiens (Diptera : Culicidae) interaction between recessive mutants and evolution in southern France. J Med Entomol 2001, 38(5):657-664.

63. Nielsen-LeRoux C, Rao DR, Murphy JR, Carron A, Mani TR, Hamon S, Mulla MS: Various levels of cross-resistance to Bacillus sphaericus strains in Culex pipiens (Diptera : Culicidae) colonies resistant to B.sphaericus strain 2362. Appl Environ Microb 2001, 67(11):5049-5054.

64. Mulla MS, Thavara U, Tawatsin A, Chomposif J, Su TY: Emergence of resistance and resistance management in field populations of tropical Culex quinquefasciatus to the microbial control agent Bacillus sphaericus. J Am Mosa Contr Assoc 2003, 19(1):39-46.

65. Commission Regulation (EC) No 1451/2007 of 4 December 2007 on the second phase of the 10-year work programme referred to in Article 16(2) of Directive 98/8/EC of the European Parliament and of the Council concerning the placing of biocidal products on the market. http://eur-lex.europa.eu/legalcontent/EN/TXT/?qid=1405494848373\&uri=CELEX:02007R1451-20130901.

66. WHO: Ultra-Low-Volume application of insecticides for vector control. Geneva: WHO; 1985.

67. Mount GA, Biery TL, Haile DG: A review of ultralow-volume aerial sprays of insecticide for mosquito control. J Am Mosq Contr Assoc 1996, 12(4):601-618.

68. Mount GA: A critical review of ultralow-volume aerosols of insecticide applied with vehicle-mounted generators for adult mosquito control. J Am Mosa Contr Assoc 1998, 14(3):305-334.

69. WHO: Space spray application of insecticides for vector and public health pest control. A practitioner's guide. Geneva, Switzerland: WHOPES; 2003.

70. Bonds JAS: Ultra-low-volume space sprays in mosquito control: a critical review. Med Vet Entomol 2012, 26(2):121-130.

71. Latham M, Barber J: Mosquito control in Florida with focus on aerial adulticiding. Outlook Pest Manag 2007, 18:178-183.

72. Thomas D, Weedermann M, Billings L, Hoffacker J, Washington-Allen RA: When to spray: a time-scale calculus approach to controlling the impact of West Nile virus. Ecol Soc 2009, 14(2):21.

73. Kline DL: Traps and trapping techniques for adult mosquito control. J Am Mosa Contr Assoc 2006, 22(3):490-496.

74. Kline DL: Semiochemicals, traps/targets and mass trapping technology for mosquito management. J Am Mosq Contr Assoc 2007, 23(2):241-251.

75. Kaufman PE, Butler JF, Nelson C: Evaluation of the Mosquito Sentinel 360 trap in Florida residential environments. J Am Mosq Contr Assoc 2008, 24(4):528-533.

76. Smith JP, Cope EH, Walsh JD, Hendrickson CD: Ineffectiveness of mass trapping for mosquito control in St. Andrews State Park, Panama City Beach, Florida. J Am Mosq Contr Assoc 2010, 26(1):43-49.

77. Loeb M, Elliott SJ, Gibson B, Fearon M, Nosal R, Drebot M, D'Cuhna C Harrington D, Smith S, George P, Eyles J: Protective behavior and West Nile virus risk. Emerg Infect Dis 2005, 11(9):1433-1436.

78. WHO: In Global collaboration for development of pesticides for public health (GCDPP): repellents and toxicants for personal protection. Edited by WHOPES. Geneva: WHO; 2000

79. Peterson C, Coats J: Insect repellents. Past present and future. Pest Outlook 2001, 12:154-158.

80. Showyin LR: Recent developments on personal protection methods against vectors. Malaysia; 2005:473-475.

81. Tawatsin A, Wratten SD, Scott RR, Thavara U, Techadamrongsin Y: Repellency of volatile oils from plants against three mosquito vectors. $J$ Vector Ecol 2001, 26(1):76-82.

82. Fradin MS, Day JF: Comparative efficacy of insect repellents against mosquito bites. New Engl J Med 2002, 347(1):13-18.

83. Andrade CFS, Cabrini I: Electronic mosquito repellers induce increased biting rates in Aedes aegypti mosquitoes (Diptera: Culicidae). J Vector Ecol 2010, 35(1):75-78.

84. Enayati A, Hemingway J, Garner P: Electronic mosquito repellents for preventing mosquito bites and malaria infection. Cochrane Database of Systematic Reviews 2007, 2:Art. No.: CD005434. 
85. Chaskopoulou A, Latham MD, Pereira RM, Connelly R, Bonds JAS, Koehler PG: Efficacy of aerial ultra-low volume applications of two novel water-based formulations of unsynergized pyrethroids against riceland mosquitoes in Greece. J Am Mosq Contr Assoc 2011, 27(4):414-422.

86. WHO: WHO specifications and evaluations for public health pesticides: Bacillus thuringiensis subspecies israelensis strain AM65-52. Geneva: WHO; 2007.

87. WHO: Safety of pyrethroids for public health use. Geneva: WHO; 2005.

88. Carr WC, lyer P, Gammon DW: A dietary risk assessment of the pyrethroid insecticide resmethrin associated with its use for West Nile virus mosquito vector control in California. Sci World J 2006, 6:279-290.

89. Peterson RKD, Macedo PA, Davis RS: A human-health risk assessment for West Nile virus and insecticides used in mosquito management. Environ Health Persp 2006, 114(3):366-372.

90. Schleier JJ, Macedo PA, Davis RS, Shama LM, Peterson RKD: A two-dimensional probabilistic acute human-health risk assessment of insecticide exposure after adult mosquito management. Stoch Env Res Risk A 2009, 23(5):555-563.

91. Andis MD, Sackett SR, Carroll MK, Bordes ES: Strategies for the emergency control of arboviral epidemics in New Orleans. J Am Mosq Contr Assoc 1987 3(2):125-130.

92. Mutebi JP, Delorey MJ, Jones RC, Plate DK, Gerber SI, Gibbs KP, Sun GH, Cohen NJ, Paul WS: The impact of adulticide applications on mosquito density in Chicago, 2005. J Am Mosq Contr Assoc 2011, 27(1):69-76.

93. Palmisano CT, Taylor V, Caillouet K, Byrd B, Wesson DM: Impact of West Nile virus outbreak upon St. Tammany Parish Mosquito Abatement District. J Am Mosa Contr Assoc 2005, 21(1):33-38.

94. Simpson JE: Emergency mosquito aerial spray response to the 2004 Florida hurricanes Charley, Frances, Ivan, and Jeanne: an overview of control results. J Am Mosq Contr Assoc 2006, 22(3):457-463.

95. Reddy MR, Spielman A, Lepore TJ, Henley D, Kiszewski AE, Reiter P: Efficacy of resmethrin aerosols applied from the road for suppressing Culex vectors of West Nile virus. Vector-Borne Zoon Dis 2006, 6(2):117-127.

96. Trout RT, Brown GC, Potter MF, Hubbard JL: Efficacy of two pyrethroid insecticides applied as barrier treatments for managing mosquito (Diptera : Culicidae) populations in suburban residential properties. J Med Entomol 2007, 44(3):470-477.

97. Lothrop H, Lothrop B, Palmer M, Wheeler S, Gutierrez A, Gomsi D, Reisen WK: Evaluation of pyrethrin and permethrin ground ultra-low volume applications for adult Culex control in rural and urban environments of the Coachella Valley of California. J Am Mosa Contr Assoc 2007, 23(2):190-207.

98. Carney RM, Husted S, Jean C, Glaser C, Kramer V: Efficacy of aerial spraying of mosquito adulticide in reducing incidence of West Nile virus, California, 2005. Emerg Infect Dis 2008, 14(5):747-754.

99. Lothrop HD, Lothrop BB, Gomsi DE, Reisen WK: Intensive early season adulticide applications decrease arbovirus transmission throughout the Coachella Valley, Riverside County. California. Vector-Borne Zoon Dis 2008 8(4):475-489.

100. Elnaiem DEA, Kelley K, Wright S, Laffey R, Yoshimura G, Reed M, Goodman G, Thiemann $T$, Reimer $L$, Reisen WK, Brown D: Impact of aerial spraying of pyrethrin insecticide on Culex pipiens and Culex tarsalis (Diptera: Culicidae) abundance and West Nile virus infection rates in an urban/suburban area of Sacramento County. California. J Med Entomol 2008, 45(4):751-757.

101. Macedo PA, Schleier JJ, Reed M, Kelley K, Goodman GW, Brown DA, Peterson RKD: Evaluation of efficacy and human health risk of aerial ultra-low volume applications of pyrethrins and piperonyl butoxide for adult Mosquito management in response to West Nile virus activity in Sacramento County. California. J Am Mosq Contr Assoc 2010, 26(1):57-66.

102. Averett $E$, Neuberger JS, Hansen G, Fox MH: Evaluation of West Nile virus education campaign. Emerg Infect Dis 2005, 11(11):1751-1753.

103. WHO: Guidelines for cost-effectiveness analysis of vector control. Geneva: WHO; 1993.

104. Zohrabian A, Meltzer MI, Ratard R, Billah K, Molinari NA, Roy K, Scott RD, Petersen LR: West Nile virus economic impact, Louisiana, 2002. Emerg Infect Dis 2004, 10(10):1736-1744.
105. Barber LM, Schleier JJ, Peterson RKD: Economic cost analysis of West Nile virus outbreak, Sacramento County, California, USA, 2005. Emerg Infect Dis 2010, 16(3):480-486.

106. Domanovic D, Giesecke J: How to define an area where transmission of arthropod-borne disease is occurring? Euro Surveill 2012, 17(20):20171.

107. ECDC: West Nile virus risk assessment tool. Stockholm: European Centre for Disease Prevention and Control; 2013.

doi:10.1186/1756-3305-7-323

Cite this article as: Bellini et al:: A review of the vector management methods to prevent and control outbreaks of West Nile virus infection and the challenge for Europe. Parasites \& Vectors 2014 7:323.

\section{Submit your next manuscript to BioMed Central and take full advantage of:}

- Convenient online submission

- Thorough peer review

- No space constraints or color figure charges

- Immediate publication on acceptance

- Inclusion in PubMed, CAS, Scopus and Google Scholar

- Research which is freely available for redistribution

Submit your manuscript at www.biomedcentral.com/submit
C BioMed Central 